January 1997

\title{
Development, change, and poverty in the informal sector during the era of structural adjustments in Tanzania
}

Joe Lugalla

The Aga Khan University, joe.lugalla@aku.edu

Follow this and additional works at: http://ecommons.aku.edu/eastafrica_ied

Part of the Political Economy Commons, and the Politics and Social Change Commons

\section{Recommended Citation}

Lugalla, J. (1997). Development, change, and poverty in the informal sector during the era of structural adjustments in Tanzania. Canadian Journal of African Studies, 31 (3), 424-451.

Available at: http://ecommons.aku.edu/eastafrica_ied/92 


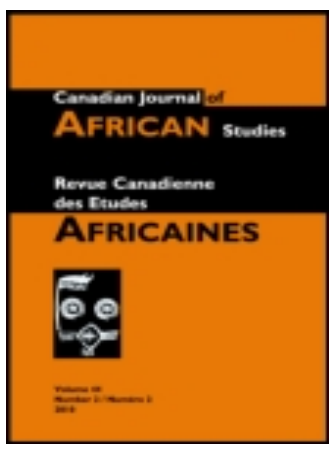

Canadian Journal of African Studies / Revue canadienne des études africaines

\section{Development, Change, and Poverty in the Informal Sector during the Era of Structural Adjustments in Tanzania}

Joe L.P. Lugalla

To cite this article: Joe L.P. Lugalla (1997) Development, Change, and Poverty in the Informal Sector during the Era of Structural Adjustments in Tanzania, Canadian Journal of African Studies / Revue canadienne des études africaines, 31:3, 424-451

To link to this article: http://dx.doi.org/10.1080/00083968.1997.10751121

曲 Published online: 30 Oct 2013.

Submit your article to this journal $\square$

Џ Article views: 127

Q View related articles ๘ 


\title{
Development, Change, and Poverty in the Informal Sector during the Era of Structural Adjustments in Tanzania
}

\author{
Joe L.P. Lugalla
}

\section{Résumé}

Le secteur informel urbain en Afrique est toujours trés dynamique et a constamment évolué en harmonie avec la nature des processus sociaux, économiques et politiques. Cette analyse du développement du secteur informel pendant la période d'adaptation en Tanzanie affirme que le secteur informel a considérablement changé: son importance, sa nature et le genre d'activités entreprises, ses participants, les relations sociales et les formes de propriété. Le secteur informel n'est plus seulement l'apanage des pauvres sans ressources, mais aussi celui de groupes sociaux à moyens revenus et de riches capitalistes. Diverses classes utilisent le secteur informel à des fins différentes. Tandis que les pauvres s'en servent pour survivre, les revenus moyens et bas le font pour supplémenter leur revenu officiel. Les riches capitalistes s'en servent eux pour s'enrichir d'avantages. La situation a exacerbé la concurrence dont les effets négatifs se sont fait sentir sur la majorité pauvre. Les décideurs de politiques se doivent de comprendre cette dynamique parce que, si l'on accorde aveuglément de l'aide à ce secteur, cette aide pourrait bien n'Itre d'aucune utilité aux pauvres sans ressources qui en ont grand besoin et sont tr $2 s$ peu assistés.

\section{Introduction}

During periods of economic crisis and structural adjustments in Tanzania, the informal sector has changed both quantitatively and

The original longer version of this paper was presented in Vienna at a conference on Neo-Liberalism and Development, organized by the University of Vienna, 2729 November 1996. I wish to acknowledge the assistance of the Economic and Social Research Foundation of Dar es Salaam, Tanzania and the Center for the Humanities at the University of New Hampshire for funding the study on the informal sector, whose findings have been used in writing this article, as well as the anonymous reviewers of the Canadian Journal of African Studies for their very constructive comments. 
qualitatively. The traditional view that the informal sector accommodates the unemployed, the poor, the unskilled, as well as utilizing family labour and local resources, is questionable in most of the sub-Saharan countries which are experiencing a severe economic crisis and have adopted structural adjustment policies (SAPs). Policy programs aimed at promoting the informal sector must acknowledge the fact that the crisis, as well as SAPs, have forced not only the poor, but also middle and upper income persons and rich entrepreneurs, to participate in this sector. Policies must reexamine the dominant forms of social relations in this sector in order to determine who actually needs assistance and how best to help them. Promoting this sector blindly might enhance the processes of social and economic inequality, exploitation, oppression, and marginalization which are currently rampant in the informal sector.

\section{Historical Context}

A decade of economic reforms in Tanzania has been associated with various social and economic impacts on different social groups in Tanzania. An indication of how adjustments have affected the conditions of life for the majority of the population is the rapid mushrooming of informal sector activities. This sector has expanded very fast and in many new dimensions during the last few years as a result of the economic crisis of the late 1970s and 1980s. This growth is part of a series of survival strategies people have adopted to weather the crisis (Tripp 1990, 49). It is now evident that the majority of the urban poor, as well as both the middle and high income urban working classes, derive or supplement their incomes from this sector. A decade ago, the wages of an average worker were capable of supporting the family of the worker and other relatives, but today most people cannot survive by depending solely on their wages and are thus forced to look for other survival strategies. As A.M. Tripp $(1990,51)$ has argued, survival requires that household heads have additional income-generating activities and that other household members, especially women and children, also practice income-generating activities. These may include agriculture, animal husbandry, sewing, food vending, shoemaking, carpentry, and hairdressing in short, anything that produces income. The advantage of the informal sector is that it produces a wide range of basic goods and 
services, most of which are consumed by a majority of the growing urban population. Therefore, if well conceived and promoted, this sector may provide an important tool for creating employment opportunities and reducing the rate of inequality and poverty.

What is happening in Tanzania is also happening in many other countries in sub-Saharan Africa which have adopted the Bretton Woods institutions' (the World Bank and IMF) prescription for economic crisis. Most of these countries, either independently or with the assistance of these institutions, as well as of NGOs and donor countries, have designed or are designing policies, whose objective is the promotion of the informal sector. These countries strongly believe that the informal sector can contribute to generating employment, promoting economic growth, and alleviating poverty. For example, in April 1995, the Ministry of Labour and Youth Development of Tanzania produced a government policy paper on micro-enterprises and informal sector promotion. Although this policy is still in the proposal stage, it is likely that, if approved, it will become the official policy to promote the informal sector. The document spells out ways and strategies which the government intends to promote the informal sector.

In order to design an appropriate policy to promote the informal sector, it is first important to understand the general processes of social change in Tanzania, particularly those which are associated with economic reforms. Second, it is crucial to examine the extent to which these changes have affected the informal sector. This reasoning is based on the assumptions that, like any other sector, the informal sector has undergone tremendous changes during the period of economic reforms (SAPs) and that one needs to fully understand these changes in order to suggest appropriate policy measures to further promote it. In order to understand these changes, an historical analysis of the development of the informal sector in Tanzania is important.

\section{Colonialism and the Development of the Informal Sector}

The informal sector is not a recent phenomena in Tanzania, but instead started to surface during the period of colonialism. The only major difference between the informal sector under colo- 
nialism and now is that it has grown quite considerably and has come to dominate the sphere of social and economic activities where the majority of the urban surplus labour force operates. During colonialism, the sector was not that significant, and the scale of informal sector activities was small. Although methods of colonization varied between the Germans and the British, setting the colonial economy in motion necessarily involved a "redirecting" of the means of production within the colony's interests and demands. Most affected was the pre-colonial social structure, including land and labour. It was this "redirecting" of the indigenous labour power that had important consequences on the social structure - for example, since then, the basic economic structure is still neo-colonial (Brain 1979, 12).

Colonialism imposed taxation to be paid in money, and the first Taxation Ordinance was enacted in 1897. The reason behind taxation was simple: it aimed at increasing the cost of living for Africans in order to force them to join waged employment. According to Sir Percy Girouard, Governor of the Protectorate of Kenya, who stated the following in the East African Standard in 1913:

We consider that the only natural and automatic method of securing a constant labour supply is to ensure that there shall be competition among labourers for hire and among employers for labourers; such competition can be brought about only by a rise in the cost of living for the native, and this rise can be produced only by an increase in the tax (Bernstein 1992, 67).

In order to get money for taxes, Africans had to migrate to either urban or rural areas to seek employment. Others had to be engaged in peasant cash-crop production. There is not much to be said about industrialization under colonialism because it was almost non-existent and colonialists viewed it negatively. For instance, in 1935, the Secretary of State asserted:

It is undesirable to accelerate industrialization of East Africa which must for many years to come remain a country of primary produce. ${ }^{1}$

The British believed that industrialization would bring ruin to the tribal society that Cameroon and his administrators were trying to retain, maintaining that the African worker who was "detribalized" in the towns was dangerous. His place, instead, was 
either in the village or working for short periods on European plantations (Coulson 1982). The process of rural-urban migration was very insignificant during colonialism because the colonial state established strict laws restricting African urban migration. One such law, the Colonial Labour Utilization Ordinance of 1923, regulated the movement of native Africans from the villages to urban areas and also made it possible for the government both to account for all blacks living in urban areas and to repatriate any of them not working to the rural areas. The place for the Africans was the countryside; very few of them were allowed to live in urban areas so that they could supply cheap labour to the European-owned businesses and the colonial government. Thus, the towns were built in such a way that they reflected the Europeans' economic and class interests. Residential segregation in terms of race and class was therefore set in motion - while Europeans lived in luxurious and very spacious areas like Oyster Bay in Dar es Salaam, the Africans were pushed away to shanty towns which were ill-planned and lacked essential basic services and facilities. Ilala and Magomeni Quarters in Dar es Salaam, for example, developed as a result of these policies.

Regardless of these restrictions, as the years passed, the number of Africans in urban areas increased mainly as a result of the following three factors. First, some Africans established permanent residence in urban areas and never went back to their rural places of origin. Second, the children born in urban areas grew up there and usually decided to remain there. Third, some of the Africans who worked as household helpers or clerks in the colonial bureaucracy remained in urban areas when their contracts ended or when their European masters went to other places or returned home. As a result, the urban population grew, as did the urban unemployment problem. When the colonial state realized that the number of unemployed Africans was increasing in urban areas, it passed laws which gave the local authorities the powers to restrict Africans to particular areas of the towns. Once land was allocated to them, Africans were supposed to live in those areas, and these areas could only be used for residential purposes. Africans were not allowed to erect business structures such as workshops or shops there. In a way, these regulations militated against the development of entrepreneurship among the Africans. 
Usually, similar to what it did in residential areas, the colonial state, operating under the umbrella of local governments, allocated specific business or trading areas for Africans. Public markets for Africans were opened in almost every urban area. The famous Kariakoo Market in Dar es Salaam is one such market. Africans were allowed to operate in these markets provided they observed the township laws - keeping the areas clean and paying the necessary market fees. Most of the goods sold in these places were supposed to be native. Africans were not allowed to trade or do business, however, in areas which were earmarked as European trading zones, such as the one in Samora Avenue (formerly called Independence Avenue) in Dar es Salaam.

Apart from restricting where Africans could trade and what they could trade, the colonial bureaucracy, because of its racist ideology and imposition of fees, also made it very difficult for Africans to obtain trading licenses or permits which were required by law. In order to circumvent these procedures, syndicates, in which a person who had a license would allow others to trade under the same license, were sometimes created. In this way, some businesses and small-scale enterprises functioned during the colonial period. ${ }^{2}$ Other discriminatory colonial policies included making sure that Africans were a reserve of cheap labour for white businessmen and the colonial government by creating "first class" markets for Europeans and "second class" ones for Africans. In addition, the colonial state established laws and regulations which limited Africans' easy access to loans and other credit sources. Such policies adversely affected the development of entrepreneurial skills among Africans and militated against the development of small-scale enterprises and the informal sector (Fapohunda 1990, 82).

However, since colonial towns were not industrial, but predominantly administrative centers, of the colonial state, they were not capable of absorbing the surplus labour force which started growing there. Hence, in order to earn a living, Africans who were unemployed began engaging in petty income-generating activities. It was these initiatives that led to the initial development of informal sector activities. Most of the informal sector activities characterizing this period were in retail trade and commerce. The well established businessmen, most of whom were of Asian origin, contracted some Africans who were 
supposed to sell their commodities (mainly clothing) in the rural areas in exchange for a minimal commission. In the beginning, the majority of those contracted by Asians were Arabs.

These people hawked commodities from house to house and from city to village. Since the business was mainly in clothing, these people were commonly known as Guo-Guo during the early to mid-1960s. This name comes from a Swahili word nguo, meaning clothing. Another type of informal business which developed during the colonial period and survived even after independence was the exchange of tradeable goods with other goods (barter). This type of business, which was popularly known as Mali kwa Mali, involved the exchange of new commodities like households utensils for used clothing. While the Guo-Guo system survived until the mid-1960s, the Mali kwa Mali way of selling things survived until the mid-1970s. Thus, colonial policies created conditions which facilitated the development of the informal sector.

\section{Post-Colonial Policies and the Development of the Informal Sector}

When Tanzania became independent in 1961, it abolished most of the colonial laws which had encouraged racial segregation and restricted rural-urban migration. This led to an unprecedented drift of Africans from rural to urban areas and a resulting rapid growth in the urban African population. For example, from 1948 to 1957, the rate of growth of the population of Dar es Salaam increased by nine percent every year, but shot up to fourteen percent from 1961 to 1967. High rates of growth for the Africans and predominantly low income populations were also notable in other smaller towns (Lugalla 1995, 27). It is now believed that twenty percent of the total Tanzanian population lives in urban areas. Urban population continues to grow, and about seventy percent of this increase is a result of rural-urban migration. Recent information (1995) collected from the Dar es Salaam City Council shows that the population of Dar es Salaam is now more than three million, and since independence, Dar es Salaam has been accommodating a third of the total urban population.

Rapid urbanization amidst economic stagnation has had serious effects in urban areas. Migrants experience severe difficulties finding not only accommodation, but also employment. They 
are forced to live in informal housing and in squatter settlements characterized by makeshift houses, where basic social service facilities are inadequate or do not exist at all. Seventy percent of the urban population in Tanzania lives in these settlements. In addition, scarcity of employment opportunities in the urban areas means that these migrants have to find employment for themselves, trying their hand at any business. The facts that the number of unemployed urban people increased after independence and that cities now became more cosmopolitan than before meant that demands for a variety of services exceeded the ability of the government to satisfy them.

People, thus, had to develop a variety of informal ways of meeting these demands. For example, the construction of informal, squatter housing emerged as a self-employed solution to the problem of urban housing. This increased amount of construction required people with carpentry, plumbing, and masonry skills. Since the possibility of formally acquiring these skills was not easily available to the majority of the poor, informal workshops which taught skills like carpentry emerged, in order to service the construction industry and to train people through apprenticeship. A growing population also brought about an increasing demand for transport systems, which, in turn, attracted the motor vehicle industry to establish both formal and informal vehicle repair workshops (garages). In addition, since not all people could afford new clothing, tailoring started mushrooming.

It is during this period that the informal sector became an important one in urban Tanzania, with most of the urban poor using it as a solution to poverty. Most informal sector participants were unemployed, possessing no skills or knowledge of business administration. In fact, most of them were untrained workers. The activities they engaged in ranged from selling vegetables and charcoal to petty trading or hawking, to carpentry and tailoring, both of which used locally available raw materials. These processes changed radically in 1967, however, because of a major shift in the politics and ideology of development in Tanzania.

In 1967, the ruling party of Tanzania, the Tanganyika African National Union (TANU), announced through the Arusha Declaration the decision to build a socialist society based on the principles of Ujamaa (traditional African way of life). The Ujamaa policy, whose focus was on rural development and self- 
reliance, not only liberalized movements, but also introduced free education and medical care. The government nationalized schools, health institutions, and the so-called "commanding heights of the economy," such as land, banks, insurance companies, and other large industries. In order to control the entire economy, the government created a variety of public companies (parastatals) to deal with some of the productive activities of the economy. A lot of privately owned institutions were nationalized. In order to accommodate village-owned shops and shops owned by public companies, the government, through the policy of "Operation Maduka," closed a lot of privately owned shops in the rural areas, as well as in some urban areas. The Villages and Ujamaa Villages Act of 1975 also played a vital role in discouraging individually owned small-scale enterprises in the villages since it decreed that all industrial units were to be owned by the village, which was supposed to function as a multi-purpose cooperative society (Havnevik 1986, 280; Tripp 1990, 55). The dominant politics of the day considered private entrepreneurship to be evil and, therefore, unwanted.

The same thing also happened in urban areas in that the government set conditions which discouraged private entrepreneurship. Services, the distribution of goods, and a variety of economic activities were supposed to carried out by state owned institutions like the Regional Trading Companies. In fact, the Board of Internal Trade was created in order to facilitate the participation of the state in commerce. These politics of development slowed the pace of the development of the informal sector from 1967 to 1980.

Beginning in the mid-1980s, however, the informal sector started growing rapidly again in Tanzania, becoming a strong force to reckon with. Why is this so? Findings from my recent study in this area indicate that the economic crisis and the economic reform policies (SAPs) which followed this crisis are the main reasons behind this development. What has been the nature of this economic crisis and SAPs in Tanzania? And how have they influenced the development of informal sector?

\section{Crisis, SAPS, and the Development of the Informal Sector (1981-96)}

Tanzania's social and economic crisis, which began in the mid- 
1970s, manifested itself in extensive and persistent internal and external macroeconomic imbalances. The internal disequilibrium was evident mainly in growing savings-investment gaps at a time when government expenditure was growing. Agricultural production declined, leading to a shortage of foreign earnings. This shortage of foreign earnings made it difficult for the government to import manufactured goods from abroad, such as fuel and industrial spare parts, thus, in turn, paralyzing the industrial sector and resulting in a progressive decline in industrial capacity utilization. Acute shortages of basic essential commodities like clothing, sugar, soap, and cooking oil resulted. Existing data also demonstrate that real agriculture output declined. The only sector that continued to expand in real terms was that of public administration and other services (Lipumba 1984, 24).

The fundamental political economy problem of Tanzania at this time was that material production was decreasing, but public administration was expanding. In Marxist terms, one would say that the superstructure had become a fetter to the development of productive forces. Such growth increased the burden of the government at a time when the government was experiencing financial resource constraints. As a consequence, the government failed to finance and maintain the service infrastructure, as well as developing a bloated bureaucracy. The quality of services such as health and education also deteriorated tremendously. Scarcity of essential commodities became the norm, a fact which encouraged hoarding, black-marketeering, and corruption. Attempts by the government to introduce a rationing system for the scarce essential items also ended up creating new contradictions. Long waiting lines resulted, first in offices to obtain permits and then at distribution points of these commodities (Lipumba 1984, 24).

Scarcity, permits, hoarding, and higher prices amidst stagnant wages led to a situation where getting things done now depended on "who knows whom," peddling, and corruption. The burgeoning inflation, which was by then between thirty and forty percent, and the higher cost of living eroded the purchasing power of the people. ILO (1982) argued that the real wage in 1980 was lower than what it had been in 1963 (ILO 1982, 273). Tanzania experienced a sixty-five percent drop in the value of real wages from 1979 to 1984, consumer prices increased tenfold from 1976 
to 1986 , and, in the same period, the ratio of minimum wage earnings to agricultural value added per worker declined by sixty percent (Tripp 1990, 49). The breakdown of the transport infrastructure, which resulted from poor roads and a lack of spare parts, meant that scarcity and exorbitant prices became more apparent and worse the farther away one lived from the town.

This situation, together with the fact that reintroduced official cooperatives started buying peasants' crops on credit, increased the hardships in rural life. Rural producers were forced to either abandon cash-crop production and concentrate on producing their own food or continue producing cash crops but sell them to parallel markets rather than to officially recognized institutions. By the mid-1980s, it had become evident that the pattern of life in Tanzania had completely changed. Life had become more difficult because of the rising cost of living. The escalating cost of living amidst stagnant incomes meant that the majority of the people in both rural and urban Tanzania started looking for extra sources of income. The deteriorating conditions of life and increased poverty in rural areas pushed people away from rural life to urban life, thus increasing the size of the unemployed urban population. In order to survive, therefore, one had to join the urban informal sector. In the mid-1980s, an influx of rural youth, commonly known as machingas, who survived by hawking, occurred in urban areas. How did the government react to this crisis? What kind of policy measures did it adopt in order to deal with it?

In order to deal with the social and economic crisis, in 1981 the government adopted a variety of its own adjustment policy measures such as "The National Economic Survival Plan" (NESP) of 1981 and "The Structural Adjustment Programme" (SAP) of 1982. Finally, it signed an agreement with the International Monetary Fund (IMF) in 1986 and adopted the "Economic Recovery Programme One/Two" (ERP I/ERP II) or ESAP (Economic and Social Action Plan) of 1986. This agreement was renewed in 1989. These policy measures sought to attain macroeconomic balance by bringing national expenditure into line with national income, to reach greater efficiency in resource allocation by carrying out resource switching across economic sectors, to reduce inflation and foreign exchange constraints by increasing 
exports and encouraging the use of locally available raw materials, and, finally, to mobilize resources over the longer term in order to raise rates of economic growth and living standards, in particular of the majority poor. What has been the impact of these policies on the development of the informal sector? To understand the impact of SAPs on the informal sector requires an understanding of the impact of SAPs on the general living conditions of the majority of the people.

\section{SAPs, Living Conditions, and the Development of the Informal Sector}

On the one hand, the crisis affected the general conditions of life for the majority of Tanzanians; on the other hand, it set in motion the rapid development of informal sector activities. Unfortunately, SAPs, which were introduced as a cure to this crisis, have not succeeded. Instead of easing the situation, they have worsened it. Devaluation of the local currency has been responsible for pushing up the prices of both locally produced and imported commodities. Reduction of government expenditures has had disastrous effects on the provision of social services and on the availability of employment opportunities in the public sector. Policies advocating the privatization of parastatals and retrenchment of workers have ended up creating more jobless people. The abolition of subsidies on agricultural inputs like fertilizers has raised the cost of production in the agricultural sector, which has, in turn, increased the prices of agricultural products and, in particular, the prices of foodstuffs in urban areas.

Although the government has been increasing the minimum wage since 1980 (from Tsh. 600 in 1981 to Tsh. 17000 in 1995 to Tshs. 30000 in 1996), this increase has never matched the rapidly rising cost of living. The price of almost every item has been shooting up rapidly during the period of SAPs, at a time when the increase in wages has been very insignificant. The net result of the stagnation of real wages and of galloping inflation for the majority of wage earners is that they have suffered a great erosion in their purchasing power during the last few years. At the same time, people are supposed to pay fees for their medical and health care services, as well as for the education of their children - services which used to be provided freely by the state. 
The question, now, is how has this situation affected the life conditions of the majority of people? Interviews with middle and upper income earners in Dar es Salaam city produced a variety of responses, such as the following:

Life is unbearable. The actual amount of money I spend for my family per month is almost three times as much as my monthly salary. I am forced to do a lot of things, legal and illegal, in order to supplement my income (a comment from one University administrator).

In the seventies, when I began working at the University as an Assistant Lecturer, I never thought that there would come a time when I could be a University Professor and a farmer at the same time. My monthly salary during those days was not more than Tshs. 1 200. Today, my monthly take home is more than Tshs. 120 000, but even though, without keeping cows and rearing chickens, things would not have worked easily (a comment from a University Professor).

Most Professors do not teach anymore. They are busy doing consultancy or attending conferences one after the other because they pay more. Consultancy is now a full-time responsibility and teaching is considered as part time to most of them. The lecturers from the Faculty of Law spent more time in courts in town than in classes. That is also their survival strategy (a comment from one University student).

In the seventies, offices were for official business only. Today, these are places used for petty trading like food, selling clothing like kanga or vitenge (women's type of clothing). Office managers have difficulties of abolishing this behaviour because the government keeps on advising people to supplement their incomes via small income generating projects (a comment from an Office Supervisor from one Parastatal Company).

These anecdotes confirm that things are now very difficult, even for the so-called middle income earners. The cost for other utilities has also gone up. A random sample, done at the University of Dar es Salaam, of twenty houses with three bedrooms each, inhabited by approximately six members and 
containing an electric cooker, indicated that the monthly electricity bill ranged between Tsh. 13000 and Tsh. 16 000. Already, this is almost a third of the salary of an Associate Professor at the University of Dar es Salaam. It is thus evident that there is a wide gap between the official incomes which people receive and the total costs of their basic needs. How, then, is this gap bridged? How do people survive?

In my previous study of urbanization and urban poverty in Tanzania (conducted in 1987-88), 280 respondents, living in Dar es Salaam, were asked to indicate their sources of extra income. Eighty-seven percent cited the importance of informal sector activities - such as petty trading, hawking, and street vendoring; eighty-five percent carried out urban farming; seventeen percent practised poultry keeping; and ten percent dairy farming (Lugalla $1995,124)$. This study was general and did not distinguish the sources of extra incomes among social classes. In the 1995 study, however, I looked at the sources of extra income by social classes. I repeated the same question regarding sources of extra income to two hundred respondents in Dar es Salaam. One hundred respondents were minimum wage earners, while the remaining one hundred belonged to middle and upper income social groups.

The findings revealed the following trends. First, both classes were now using the informal sector in order to supplement their official incomes. Second, the class position of individuals determines a great deal about the nature of survival strategies. Incomegenerating activities which do not require much capital or fixed premises and which are easy to handle seem to be the domain of the low income earners. These include petty trading, hawking, selling cooked meals in shanty hotels, and metal works (garages). Urban farming, dairy cattle, poultry keeping, grocery kiosks in wooden or metal containers, and women's hairdressing saloons seem to be the domain of middle and upper income classes.

What is interesting is that while, on the one hand, low income people do not participate in activities of the higher income classes, on the other hand, relatively better off individuals are increasingly joining in activities which were traditionally the domain of the desperate urban poor. Although these findings assist in understanding how people survive and how the nature of informal sector activities and their operation have changed, they nevertheless do not reveal much about the nature of social rela- 
tions in the informal sector. The fact that these activities are now part of the urban economy and are becoming increasingly dominant means that it is important to know who benefits and who suffers from these relations or what these changes mean to the majority poor.

In order to examine the nature of social relations in the informal sector, I asked the informal sector participants belonging to middle and upper income classes to explain how they participated in the informal sector activities, keeping in mind the fact that most of them were employees in the formal sector. Seventytwo percent stated that they hired other people and paid them a monthly wage. Nineteen percent hired people, used family labour, and also participated physically in informal sector activities after office hours. Nine percent indicated that they were being assisted by relatives (family labour). Those who hired people indicated paying a monthly wage of between Tsh. 6000 and 8000 . Four respondents paid their labourers between Tsh. 10000 and 12 000, and only two paid the minimum wage (Tsh. 17 000). Those who kept dairy cattle indicated they employ youths (boys) aged from the ages of eighteen to twenty-four, whose responsibility was cutting grass and milking the cows. None of them paid these boys a monthly wage exceeding Tsh. 6000 .

Then, I randomly surveyed two hundred informal sector enterprises in order to examine issues related to the ownership, class, and social status of informal sector participants who worked physically on the premises. The general age of participants seems to range from twenty to forty-five, a fact which shows that youths and younger adults tend to dominate in the informal sector. While the owners of eighty-eight out of two hundred enterprises (fortyfour percent) themselves work at the enterprise, seventy-eight enterprises (thirty-nine percent) were owned by middle and upper income people who worked in the formal sector. Thirty-four enterprises are owned by business people (entrepreneurs) who also own business enterprises elsewhere.

What does one learn from these findings? While employees from the formal sector are using their informal sector for survival purposes, lack of government regulation, which means that the possibility of both evading tax and breaking labour laws is high, attracts some capitalists. These people are increasingly investing in this sector, not for survival purposes but more for accumulation 
of profits and capital. The informal sector operators who own the enterprise and work physically on the enterprise's premises feature most in marginal, unattractive, low-profit making activities like manual sand and stone quarrying, cutting and selling grass along highways, small scale repairing services like car mechanics, household selling stalls, and the selling of cooked foods in shanty hotels ("Magenge"). These activities are increasingly becoming the domain of the very desperate urban poor. The returns they get from these activities barely suffice beyond subsistence. Income generating activities which have good returns but require also a reasonable amount of financial investment such as wood and metal works, tailoring, grocery kiosks, women hair saloons, construction industry materials like cement, informal bottled beer pubs, and restaurants are nowadays increasingly being operated by people who can afford the initial investment costs.

In order to understand more about the nature of social relations in the informal sector, I also examined the levels of participation by both the gender and social position of participants. Of the 535 people engaged in these enterprises, 360 (67.3 percent) were males and 175 (32.7 percent) were females. Men featured most in wood and metal works, auto-mechanics, brick-making, tailoring, wood carving, grilled meat stalls, tire repair, leather works, and dairy cattle grass cutting. Women, in most cases, participate in hairdressing salons, stone and sand quarrying, cooked foods, and in the entertainment industry.

Of the 215 enterprise owners, 164 (76.3 percent) were males and 51 (23.7 percent) were females. The fact that the 200 enterprises engaged 535 people indicates clearly the potential of this sector to absorb the surplus urban labour force. However, if one looks at the status of people in the informal sector, a different picture emerges as far as processes of marginalization are concerned. The findings show that a total of 434 out of 535 persons (81.1 percent) operated in the informal sector not as owners of the enterprises, but as labourers. Of these, 288 (66.4 percent) were males and 146 (33.6 percent) were females.

\section{The Nature of the Informal Sector}

SAPs have not meant the same thing to everyone in Tanzania. As demonstrated elsewhere (Lugalla 1997, 61-81), SAPs have created 
wealthy individuals and have increased imported luxurious consumer items; availability of foreign exchange is no longer a problem; and luxurious buildings are mushrooming simultaneously with squatter, slum settlements. All of these are not isolated processes but are instead just two sides of the same coin. Statistics from the Planning Commission of Tanzania reveal that SAPs have increased the rate of economic growth in Tanzania to a four percentage rate since 1986. Clearly, there is also concrete evidence that SAPs have improved the quality of informal sector services and production. What do SAPs mean to the daily life of the Tanzanian majority, and how has this situation affected the informal sector? Who has suffered most and how?

Economic hardships resulting from the crisis and economic reform policies have forced a majority of people to use the informal sector as a survival strategy. With the rapid development of the informal sector both quantitatively and qualitatively, the informal sector of the 1970s has changed both in form and content, particularly in terms of informal sector activities, the nature of participants, the social relationships, the forms of ownership, and the types of activities done and services provided.

The size of an enterprise is commonly measured in terms of the number of workers engaged or capital invested in the business. Anyone who has lived in Dar es Salaam during the past ten years has probably observed the growing number of informal sector activities which have flooded the central business district of the city and the sidewalks of highways and streets. Urban streets are now flooded with hawkers ("The Machingas"), grocery kiosks selling everything, informal pubs, and fast food restaurants. Areas which were originally restricted zones for any type of business are now flourishing with different types of retail trade. A 1991 national study indicated that some 950103 people were operating in the urban informal sector. In the early 1960s and 1970s, the informal sector consisted primarily of locally produced materials and not imported manufactured goods. Today, the "machinga" hawkers sell everything from clothing, tool kits, spare parts, electronic equipment, television antennae, car fittings, recorded music video cassettes, cameras, mattresses, household equipment, mosquito nets, bags, suitcases, and cosmetics. The list is endless. Petroleum products such as industrial and motor vehicle 
oils, grease and other lubricants, and sometimes fuels like paraffin, diesel, and petrol - which never featured in informal sector operations in the 1970s - are today found in every corner of the city.

\section{Nature of Social Relations, Forms of Ownership, Participation, and Problems Encountered}

Studies of the informal sector in Tanzania and elsewhere still view the informal sector activities as the domain of the urban poor and the people who participate in this sector as unskilled or having acquired these skills informally. The policy makers of Tanzania seem to hold this perspective. My research findings, however, indicate significant changes in the informal sector. The post-colonial period in Tanzania has been characterized by a variety of social processes such as free and universal primary education and the expansion of both institutes of higher learning and employment opportunities in the private and public sectors. Hence, by late 1970s, Tanzania already had primary school graduates operating in this sector. People with secondary education did not participate in this sector at that time because opportunities for formal employment were abundant and their wages provided for their basic needs. Today, however, many high school leavers and university graduates work in the informal sector. Although this has increased competition in the informal sector, it has also led to a tremendous improvement of the quality of both services and products in this sector.

The crisis and the SAP policies have brought a number of changes. First, employment opportunities have become scarce because of the reduction in government expenditure, privatization, or abolition of some of the parastatal companies. Retrenchment policies have created more jobless people than they have economic growth. Second, the cost of living has gone up tremendously amidst stagnant wages. All these processes have generated more poverty than wealth for the majority of Tanzanians. Tanzanians can now be divided into the "new poor" and the "chronic poor." The former are those people who were relatively better off before the economic crisis and the SAPs, either as low, middle, or upper income earners, but who, as a result of economic crisis and SAPs, have now been pushed below what economists would label as the "poverty line." The latter are 
those who were already poor (below poverty line) even before the crisis and SAPs came, but who have not been spared by the crisis and SAPs. Their situation has worsened rather than improved. While the "chronic poor" are those who have been using the informal sector as a "safety net" for many years, the "new poor" have been forced to join the activities of the informal sector in order to supplement their official incomes.

The findings from my study reveal that even the so called wealthy individuals, ("entrepreneurs") are increasingly invading this sector, not in order to survive or supplement their incomes, but in order to enhance their processes of capital accumulation. This qualitative change has had disastrous effects on the informal sector. There is now stiff competition between the "entrepreneurs," the "new poor," and the "chronic poor." Most of the "entrepreneurs" and the "new poor" have formal education and formally acquired skills. Most of the "new poor" who have joined the informal sector are permanent employees in the formal sector with permanent jobs, stable incomes, social security, and security of tenure. To them, survival during the era of SAPs is not a matter of life or death. The fact that some of them work in the public sector and some in the formal private sector means that most of them have connections and contacts. The relationship between these two social classes and the "chronic poor" is not harmonious, but contradictory and exploitative. The informal sector is now an arena of competition, exploitation, and struggle between the desperate "chronic poor" and the others.

The findings from this study demonstrate that the relatively better off participants are winning. In a virtual "zero sum game," the "chronic poor," who desperately need the informal sector in order to survive, are increasingly being relegated to the position of labourers rather than owners. The wages they get as labourers are below the required minimum wage. Further, when it comes to getting credit or loans from banks or other sources in order to develop small scale enterprises, it is the "entrepreneurs" and the "new poor" who stand a better chance because of the following reasons: they are well informed and more likely to be aware of the existence of such credits; they know the formalities involved in applying for a loan; they know how to prepare project proposals; they have permanent jobs, which means they can guarantee the banks that they are capable of repaying the loan and this makes 
them credit-worthy; they are capable of paying the down payments; they have management skills and are bound to be more economically successful than the "chronic poor," whose projects survive by sheer luck. Reliable information from some banks show that it is people with these qualities who have been benefitting from special credit schemes aimed at promoting the informal sector. One of the informants had the following remarks about such schemes:

Hiyo mikopo ni maneno tu! Nilijaribu mara moja nikashindwa. Waliniambia kuwa nitayarishe vizuri maada ya mradi wangu ili nifikiriwe. Mimi sijui maana yake. Lakini nimeona akina mama wenzangu, wake wa wakubwa, wana kazi zao nzuri, wana mgari ya binafsi na ya kazini pia ambao wamepata hiyo mikopo. Wengine zaidi ya mara moja. Hebu angalia ile Pajero ST iliyosimama pale. Imejaza mifuko ya chakula cha kuku na majani ya ng'ombe. Hao ndio wanaopewa mikopo. Siyo sisi "Walala-Hoi."

These credit schemes are mere words. I tried once but failed. They told me to prepare a project proposal. I did not know what they meant. However, I have seen my fellow women, wives of people with power, they have good jobs, have access to both private and officially owned cars who have been granted such loans. Some of them more than once. Look at that government owned Pajero car standing there. It is fully packed with bags of chicken feed and green grass for cows. These are people who get loans, not we, the poor (my translation).

One of the major changes in the informal sector is the rapid increase of women participants in general, and, in particular, in the kind of activities which used to be predominantly operated by men. Earlier studies show that women participated mainly in household and domestic related activities like selling cooked food and working in the entertainment industry. The findings indicate, however, that presently, men are increasingly working as bar or restaurant attendants, occupations which used to be predominantly female. The dire need to survive, which seems to be a process of almost hunting and gathering whatever is available, has led to gender blindness as far as survival strategies are concerned.

Women are now increasingly participating in petty 
commodity production in order to supplement household incomes. But their traditional role in the domestic sphere of life as producers and reproducers has not changed significantly, which means that their burden is increasing with deleterious effects on their social status and health.

The policies of liberalization, which go hand in hand with the winds of Westernization or modernization, have also brought in Western styles of beautification. Western hair styles which involve straightening hair with heat or cold creams are now very popular with women. The result has been a rapid proliferation of women's hairdressing saloons and mini shops selling the kinds of cosmetics which go along with this. Since these are expensive lifestyles and one needs sophisticated connections in order to get perfumes, creams, and curling equipment, most of which are imported, those who participate in this business are either middle or upper class women, and they also provide services to the same. Thus, survival strategies are not neutral of class relations and the winds of modernization and other processes which are polarizing classes are now redesigning the nature of the informal sector. What are the implications of these processes?

Reading through this description of informal sector activities and their mode of operation, one might think that there are more advantages than problems. In reality, however, there are risks and constant harassment from the government precisely because, according to the law, most of these activities are considered illegal. Following established procedures means that one has to apply for a license, which calls for fixed premises and the payment of a tax, in addition to complex and expensive red-tape. Moreover, there are also disadvantages of operating a business outside the country's legal framework. One has to operate the business under the psychological pressure of uncertainty. Many hawkers, street vendors, and other informal sector operators have to walk with some money in their pockets ready to bribe the authorities in order to encourage them to look the other way. The money paid as bribe buys them nothing beyond the freedom to try to earn a living (Rossett 1987, 4).

In addition, the government has enacted several laws which coerce the unemployed in urban areas. For example, in 1983, the government enacted a Penal Code amendment which banned from cities "idle and disorderly persons" involved in so-called 
"unproductive" activities. A year later, it passed the Human Deployment Act, requiring all Tanzanians to be registered and provided with labour identification cards. Those who could not meet these requirements (including the self-employed) were to be settled in the countryside. Various studies show that most of the people who operated in the informal sector were lumped into this "idle and disorderly category" and treated as "loiterers" (Tripp 1990; Lugalla 1990, 1995). In fact, President Nyerere, while emphasizing this policy directive, said that, "if we don't disturb loiterers, they will disturb us." The so-called loiterers were compared with economic saboteurs and racketeers "whom the nation has declared war on" (Daily News 26 September 1983: 1; Tripp 1990, 57).

Since then, the coercive instruments of the state have used these laws to harass informal sector operators. Evidence from this study reveals that it is always the desperate poor who have become victims of police harassment. For example, after waiting a long time to round up all the street vendors and hawkers popularly known as "machingas" in the famous "Congo Street" in the Kariakoo area of Dar es Salaam, the City Council implemented its decision in early August 1993 by ordering the Field Force Unit of the police to round up all the vendors and hawkers (Lugalla 1997, 78). The "Human Resources Deployment (Nguvu Kazi) Act," which became effective in 1983, is always used by the state to achieve these ends. Despite these pressures, the informal sector has kept on growing, and there is a clear indication that the coercive measures adopted by the state against the informal sector are simply solving the symptoms rather than the essential problems of relations.

\section{The Future of the Informal Sector}

The findings of this study confirm that the informal sector possesses the potential to continue contributing to the development of the economy and to skills training in particular. It is evident that the sector will also continue to be a source of employment opportunities for the majority of the urban poor, as well as a strategy for survival and capital accumulation for some social groups. Consequently, any policy aimed at developing the informal sector must seriously consider the following issues. First, it must examine the social processes of change within the 
informal sector in order to identify the key participants. It must also know which participants use the informal sector for survival purposes, which ones use it to supplement their incomes, and which use it to accumulate more profits and capital. Second, and, in fact, related to the first, it is important to know which participants need to be assisted and how. The objectives of policy formulation must therefore be guided by a specific direction. The important guiding question should be: Should policy promote the informal sector so that it contributes to economic growth? Or should policy promote this sector so that it generates economic growth and contributes to alleviating poverty and social and economic inequalities? How should Tanzania and other countries in sub-Saharan Africa proceed?

Article 5 of the Preamble of the 1988 Khartoum Declaration, "Towards a human focused approach to socio-economic recovery and development in Africa," states:

Since the human being is the center of all development, the human condition is the only final measure of development. Improving that condition is essential for the poor and vulnerable human beings who comprise the majority of our peoples in Africa. Africa's men and women are the main factors and the ends for whom and by whom any programme and implementation of development must be justified.

Similarly, the 1995 World Social Summit which took place in Copenhagen emphasized three main themes on which any development strategy for Africa has to focus. These themes are: alleviation of poverty, elimination of unemployment, and enhancement of social integration. Policies aimed at promoting the informal sector must also pay direct attention to these three themes. The Khartoum Declaration, as well as the three themes of development suggests that, "development," above all, is about people. Development programmes must therefore be human oriented and must strive to improve the conditions of life for the majority of the population. Hence, policies intending to promote the informal sector must aim at improving the social and economic conditions of life for the majority of people. Is this happening in Tanzania and other countries of sub-Saharan Africa? Evidence from Tanzania indicates that it is far from accommodating the spirit of the Khartoum Declaration in its development plans. It is doubtful whether the three themes of development identified during the 
Copenhagen summit are now integrated in Tanzanian politics.

In attempts to promote the informal sector, it is evident that development plans of Tanzania continue to believe that this sector is occupied by the urban poor - the unskilled who lack formal training - and thus relies on locally available resources and raw materials, family labour, and easy entry. These plans do not therefore acknowledge the changing nature of the informal sector. It is doubtful whether policy formulators understand the qualitative changes which are taking place there. Lack of this kind of analysis has led to a situation where informal sector policy programs have ended up hurting would be beneficiaries. Existing informal sector policies in Tanzania do not spell out which activities will be supported and how. Identifying such activities is important because the informal sector is very broad in terms of its activities and very mixed in terms of its participants.

At present, the informal sector can be divided into two main groups. First are the so called "Modern Activities" (modern or traditional only in terms of how and where they operate) like motor vehicle repair, hair dressing salons, carpentry, metal works workshops, and others. These activities take place in specific fixed premises. Most of them are now owned and controlled by people working in the formal sector who have formally acquired education and skills. Second are the "Traditional Activities" like hawking, petty trading, the selling of cooked food in streets, and others. Such activities do not have fixed premises, are highly mobile, and, in most cases, are operated by the very poor. Historical evidence, as well as the results from this study, indicates that all policies which claim to promote informal sector activities tend to focus on the "modern activities," and not on the "traditional ones."

It is these activities which benefit from established credit schemes. For example, SIDO has existed since 1973. Credit schemes have been operating for the last few years. But evidence from studies, including this one, reveals that those who benefit are not always the desperate poor. It is also important to acknowledge that informal sector operators know how to organize their business. They have informal associations or cooperatives which assist them in organizing their activities. Some operators have informal credit schemes which work very well. Social networks based on ethnicity also need to be explored in order to understand 
how they operate in the informal sector. The "Upato" system among women, which involves the lending of money to the members of the group on a rotational basis, is a case in point. It seems that, rather than thinking that informal sector operators are ignorant and disorganized and that, therefore, the government can superimpose institutions on them, it is better to learn from the initiatives of informal operators themselves and then proceed in creating policies which are a product of these initiatives. Such policies are bound to easily accepted and sustainable, and they may bring positive fruits.

As O.J. Fapohunda (1990) has noted that for Zambia, in an attempt to promote the informal sector, the government must also distinguish at least three roles on the basis of which the informal sector can be developed. First, a static role exists in which informal sector activities fill up vacant economic spaces in the economy, thereby increasing the efficiency of formal sector activities through backward, forward, and lateral linkages and also thereby satisfying hitherto unsatisfied consumer and producer needs. The growth of such activities is essentially determined by, and derived from, the structure and performance of the formal sector. Second, an evolutionary and dynamic role exists in which some informal sector activities autonomously expand on the basis of efficiency, economies of scale, and diversification, thereby transforming themselves into formal sector activities. Since this second role might ruin the weak informal sector activities, the government must make sure that it protects and assists those activities which accommodate the most needy, but least assisted, persons. Hence, the third role of the informal sector should be seen not only from an economic point of view, but also in terms of alleviating poverty of the majority of the population and eliminating social economic relations of exploitation and inequality. The government must ensure that the majority of the poor have access to loans and other forms of credit schemes.

The informal sector activities which fulfill the static role are those characterized by petty trading, hawking, and street vending. The activities associated with the second role are those enterprises that increase the value-added products. These include small-scale farming, manufacturing, and processing. Experience from other countries demonstrates that many governments find it difficult to design policies to promote the static role and, there- 
fore, fail to implement the third role. Governments feel that the enterprises which fulfill the second role deserve promotion. Tanzania holds this belief too.

\section{Conclusion}

The optimistic view held by most development planners that the growth of the informal sector is an open-ended process with wide chances for everyone to participate and succeed must now be doubted. The situation in Tanzania suggests more pessimism than optimism about the development trend and change in the informal sector during the era of social economic crisis and SAPs. The road to expansion varies; it is both arduous and cumbersome. While to some it is open and very easy, to others it is blocked and very restrictive as a result of exploitation and marginalization. The economic crisis and the accompanying SAPs contribute a great deal to enhancing these processes by reducing the number of state employees and drastically undermining their real incomes through inflation. As H. Bernstein has argued, "in the discourse of neo-liberalism, this was a brutal but necessary adjustment" (1992, 77).

The development of the informal sector is not just an outcome of pressures and constraints, but is, above all, an issue of class, shaped by the relations of social economic inequality which are dominant in Tanzania. The dangers of marginalization and exploitation in the informal sector are real, but their conditions and magnitude vary from one type of activity to the other. In this case, generalizations are difficult. Therefore, the government needs to carry out in-depth studies in order to design policies which are specific. The fact that the informal sector is fragmented, diversified, and mixed in terms of activities, participants, and modes of operation confirms that it is, indeed, difficult to adopt a blanket policy to promote the informal sector.

In developing policies to promote the informal sector, it is important to distinguish between macrolevel and microlevel actions. While the former are the responsibility of the state or central government, the latter can be carried out more effectively by the informal sector operators themselves by means of their associations and any other forms of organizations. The local governments can also play a vital role at this level. In order to understand what can be done at the microlevel, it is essential to 
differentiate between "survival" and "growth." The informal sector acts as a survival sector for a majority of the poor people and will continue to play a role irrespective of positive or negative intervention from policy makers. What is at issue here is how to stimulate growth within the informal sector without superimposing conditions which might end up formalizing these informal survival processes.

It is also important to emphasize that promoting the urban informal sector is just a short-term solution to the problems of urban unemployment and urban poverty. A long-term solution requires addressing the process of rural-urban migration. It is rural poverty which is pushing a lot of people to the urban areas. As the Director General of UNICEF has observed, "it is widely known that the poor have usually gained least in good times and suffered most in bad times" (Bernstein 1992, 77). Overall, social economic development policies which focus on improving rural and urban life conditions (balanced development) might lead to a lasting solution. This should be in the minds of development planners in Tanzania; otherwise, they risk putting the cart before the horse.

\section{Notes}

1 This statement was made by the Secretary of State for colonies and quoted by the Governor of Tanganyika in 1935.

${ }^{2}$ Fapohunda (1990) has noted a similar trend in Zambia.

\section{Bibliography}

Bernstein, H. 1992. "Agrarian Structures and Change: Sub-Saharan Africa." In Rural Livelihood: Crises and Response, edited by H. Bernstein et al. London: Oxford University Press.

Brain, A. 1979. "The Political Economy of Urbanization in Tanzania." PhD thesis, University of British Columbia.

Coulson, A. 1982. Tanzania: A Political Economy. London: Clarendon Press.

Fapohunda, O.J. 1990. "Small Scale Industry and Training in Zambia." In Kleinbetriebe des informellen Sektors und Ausbildung im subsaharischen Afrika, edited by U. Boehm and R. Kappel. Institut Fuer Afrika-Kunde, Hamburg.

Havnevik, K.J. 1986. "A Resource Overlooked: Crafts and Small-Scale Industries." In Tanzania: Crisis and Struggle for Survival, edited by 
J. Boesen, K.J. Havnevik, J. Koponen, and R. Odgaard. Uppsala: Scandinavian Institute of African Studies.

ILO. 1982. Basic Needs in Danger, A Basic Needs Oriented Development Strategy for Tanzania. Jobs and Skills Program for Africa, Addis Ababa.

Lipumba, N.H.I. 1984. Economic Stabilization Policies in Tanzania. Economics Department and Economic Research Bureau, University of Dar es Salaam.

Lugalla, J.L.P. 1990. "Socialist Construction and the Urbanization Process in Tanzania: An Analysis of Urban Poverty and Politics." $\mathrm{PhD}$ thesis, University of Bremen, Federal Republic of Germany.

-. 1995. Crisis, Urbanization, and Urban Poverty in Tanzania: A Study of Urban Poverty and Survival Politics. Lanham, Maryland: University Press of America.

—. 1997. "Where Do the Majority Live in Urban Tanzania: Why and How?" In Globalization and Survival in the Black Diaspora: The New Urban Challenge, edited by C. Green. New York: State University of New York Press.

Rossett, C. 1987. "Peru's New Economic Order." In The Informal Economy. CUSO Journal, December.

Tripp, A.M. 1990. "The Informal Economy and the State in Tanzania." In Perspectives on the Informal Economy, edited by Estellie M. Smith. Lanham, Maryland: University Press of America. 